\title{
Utilizing Production Sharing Contracts (PSCs) as a Means for the Protection of Indonesia's Natural Resources
}

\author{
Hari Sutra Disemadi \\ Diponegoro University, Indonesia \\ haridisemadi@gmail.com
}

Sahuri Lasmadi

Jambi University, Indonesia

slasmadi@gmail.com

\begin{abstract}
Indonesia has the potential to manage natural resources in such a way that social justice, public welfare, and the prosperity of the people is also realized. Contract law is the primary legal umbrella used in efforts to protect natural resources from exploitation. This study uses normative juridical methods that prioritize secondary data as the primary sources. This study shows the form of the legal protection of state assets related to oil and gas management including the government has the right of immunity, the existence of provisions regarding state revenue, state levies, and bonuses and the existence of provisions for contractors to distribute a portion of the production share. Thus, the government uses Production Sharing Contracts (PSC) to enter into oil and gas management agreements with contractors, specifically regarding upstream business activities. The Oil and Gas Law does not elaborate on the meaning of the PSC. Rather, it only states that the PSC is one form of the contracts.
\end{abstract}

KEYWORDS: Production Sharing Contract, State Control, Protection of Natural Resources.

Copyright $\odot 2019$ by Author(s)

This work is licensed under a Creative Commons Attribution-ShareAlike 4.0 International License. All writings published in this journal are personal views of the authors and do not represent the views of this journal and the author's affiliated institutions.

\section{HOW TO CITE:}

Disemadi, Hari Sutra \& Sahuri Lasmadi. "Utilizing Production Sharing Contracts (PSCs) as a Means for the Protection of Indonesia's Natural Resources" (2019) 6:3 Lentera Hukum 397412.

Submitted: August 04, 2019 Revised: September 20, 2019 Accepted: October 01, 2019 


\section{INTRODUCTION}

Article 33 paragraph (3) of the 1945 Constitution states the land, water, and natural resources contained within the state are subsequently controlled by the state and are to be used as much as possible for the prosperity of the people. The affirmation of this article is structured to ensure the welfare of the people. Indonesia's natural resources, particularly coal and oil resources, play an essential role in the national economy. To this end, the government possesses authority to carry out exploration and exploitation of oil and gas in the form of Mining Authorizations. Law No. 22/2001 on oil and gas states that exploration is an activity carried out to obtain information on geological conditions, which may then be used to find and obtain estimates of oil and gas reserves. It emphasizes that exploitation is a series of activities aimed at producing oil and natural gas. These activities include drilling and completing wells, constructing infrastructure for transportation and storage of materials, and processing facilities for the separation and purification of oil and gas in the field. ${ }^{1}$

This natural resource management should maximally guarantee the welfare and prosperity of the people so that management activities may be carried out correctly. Contracts, specifically Production Sharing Contracts (PSC), are an essential legal instrument by which this may be done. ${ }^{2}$ The PSC is a specific tool used to overcome problems that arise during the exploration and exploitation of oil and gas mining. These problems are often related to obstacles posed by limited capital, technology, and human resources. This type of contract is one of cooperation implemented to provide protection for State assets and provide benefits to the State. Cooperation Contract conducted the government and the contractor, known as a Business Entity, and a Permanent Establishment during the establishment of the last. A Cooperation Contract is crucial because it is an agreement between many parties that have an interest in oil and gas. This collective interest creates an urgency to protect State assets through oil and gas management.

This research investigates how PSCs protect natural resources as assets of the Indonesian State. A normative/doctrinal juridical approach was employed to collect data. It included a literature review, while data analysis consisted of Normative Normative Qualitative Analysis. Data analysis is categorized as qualitative because it relies on the depth of data with descriptive-analytical methods.

\section{OIL AND GAS AS NATURAL RESOURCES CONTROLLED BY THE STATE}

PSCs are cooperative contracts regarding the exploration and exploitation activities used by the State to ensure the greatest prosperity of the people. PSCs involve the

$1 \quad$ Hernandoko, A., \& Imanullah, M. N., "Implikasi Berubahnya Kontrak Bagi Hasil (Product Sharing Contract) ke Kontrak Bagi Hasil Gross Split Terhadap Investasi Minyak dan Gas Bumi di Indonesia," Privat Law, 6(2), 160-167, (2018) at 168.

2 Arizona, Y., "Perkembangan konstitusionalitas penguasaan negara atas sumber daya alam dalam putusan Mahkamah Konstitusi”, Jurnal Konstitusi, 8(3), 257-314, (2011) at 259. 
government. Contracts involving these state authorities as a party are also commonly known as government contracts. Simamora translated the term with a government contract. ${ }^{3}$ When the government enters into contractual relationships on a private scale, they hold a dual role. They hold the same position as any other private subject would, but their position as a public body is not released. ${ }^{4}$ When the government agrees to private status, it must ensure that it obeys special rules. All legal consequences arise due to the relationship are consequences resulting from the application of legal principles and rules in the field of civil law. These may be material or formal. ${ }^{5}$ Essentially, the government is liable to be sued.

\section{A. The Principles, Rights to Control, and Authorities of the State}

State power over natural resources begets state control, wherein the rights to control include the authority to regulate, supervise, and manage all forms of management and potential exploitation of natural resources. The authority inherent in the State, as carried out by the government in this case, is an authority granted by the 1945 Constitution through Law No. 22/2001 on Oil and Gas (Oil and Gas Law). This law clarified that state authority over natural resources should also the law used to help realize goals related to social justice and the general welfare of the people..

Based on the relationship between the Ownership Rights of the State and the object of ownership, ${ }^{6}$ the State's Ownership Right must be understood in the context of the State's rights and obligations. These include those related to the State is the owner (domain) which is publiekrechtelijk, not the eignaar, which is privaaterechttelijk. ${ }^{7}$ The government stated in the provisions of Article 6 of the Oil and Gas Law, paragraph 2 letter an (attributive authority), namely ownership of natural resources, remains in the hands of the government until the point of delivery. However, State Ownership Rights also maintain private aspects, such as when a legal relationship exists between the State, itself, a public legal entity, and a private/private legal entity (BUMN, BUMD, Cooperative, Foreign Company/Business Entity, and PMA). In the case of oil and gas exploitation, this has to do with upstream activities and downstream activities. It happens when authorized by the government, carries out the function of taking care of the object of natural wealth, ${ }^{8}$ which is based in the form of a cooperation agreement. In such circumstances, according to Kranenburg and Vegting, the authorities of State or government act as organs of public bodies in the form of private rechtpersoonlijkeheid. ${ }^{9}$

Simamora, Y.S., Prinsip Hukum Kontrak Dalam Pengadaan Barang dan Jasa Oleh Pemerintah, (Yogyakarta: Laksbang PRESSindo, 2009), at 55.

4 Adha, L. H., "Kontrak Build Operate Transfer Sebagai Perjanjian Kebijakan Pemerintah Dengan Pihak Swasta," Jurnal Dinamika Hukum, 11(3), 548-558, (2011) at 551.

5 Simamora, Y.S., supra note 3 at 93.

6 Asikin, Z., "Perjanjian Kerjasama Antara Pemerintah dan Swasta Dalam Penyediaan Infrastruktur Publik" Mimbar Hukum-Fakultas Hukum Universitas Gadjah Mada, 25(1), 55-67, (2013) at 61.

7 Simamora, Y.S., supra note 3 at 33.

8 Disemadi, H., \& Roisah, K., "The Enforcement of Business Competition Law by the Police: An Indonesian Experience", Lentera Hukum, 6(2), 203-212, (2019) at 207.

9 Simamora, Y.S., supra note 3 at 58. 
The role of the State is that of being the holder of power. As a result, the State has the authority to grant power to business entities or individuals to undertake the exploitation or management of excavated materials under the Indonesian mining jurisdiction. The provisions of Article 4 of the Oil and Gas Law confirm this. These provisions state: 1) Oil and gas are strategic non-renewable natural resources categorized under the Indonesian mining jurisdiction and are national assets controlled by the State; 2) State control as stipulated in paragraph (1) is held by the government as the holder of the mining authority; and 3) The government, as the holder of the mining authority, composes the Implementing Body as referred to in Article 1 number 23.

\section{B. Duties and Authorities of the Government}

In the 1945 Constitution, Article 4 states that the President holds the power of the government. Article 17 states that the president, while running the government, is to be assisted by State ministers in the execution of specific government affairs - one of these ministers of that of Energy and Mineral Resources (EMR). The functions and authorities attributed to the Minister of Energy and Mineral Resources, as stated in Article 12 of the Oil and Gas Law, include: 1) Determination of the working area to be offered to a business entity or permanent establishment after consultation with the regional government; 2) Offering of the work area, as referred to in paragraph (1), and 3)Responsibility to deem or reject requests from business entities or permanent establishments to carry out exploration and exploitation business activities in the work area as referred to in paragraph (2).

In 2003, the Constitutional Court issued a decision stating that Article 12, namely paragraph 3, was considered to conflict with Article 33 of the 1945 Constitution in Decision of the Constitutional Court No. 002/PUU-I/2003. It concerned the Test Material of the Oil and Gas Law against the 1945 Constitution. The Constitutional Court Decision can be translated such that the words "given authority" mean that ministers, based on the law, can lend available public authority to the Business Entity or Business Form Permanent. ${ }^{10}$ More specifically, the Minister of Energy and Mineral Resources possesses authority over technical matters on guiding and supervising ${ }^{\text {ll }}$ activities relating to exploration and exploitation of oil and gas, as mandated. It includes supervision over the Director-General of Oil and Gas, who leads the Directorate General of Oil and Gas. Both the Minister of Energy and Mineral Resources and the Directorate General of Oil and Gas possess the authority to issue various licenses related to the activities of exploration and exploitation, ${ }^{12} 13$

In Article 4 of the Government Regulation No. 35/2004 on Upstream Oil and Gas Activities (PP No.35/2004), Government Regulation No. 34/2005 on the Amendment to Government Regulation No. 35/2004 (PP No. 34/2005), states that the Minister must

10 Setyadi, D.S., Aspek Hukum Administrasi Eksplorasi dan Eksploitasi Minyak dan Gas Bumi di Indonesia, (Surabaya: Nusantara Makmur, 2007), at 36.

11 Adha, L. H., supra note 4 at 556.

12 Asikin, Z., supra note 6 at 63.

13 Setyadi, D.S., supra note 10 at 33. 
determine policy for offering Work Areas based on technical, economic, risk levelrelated, efficiency-related concerns. Further, these decisions must be based on openness, fairness, accountability, and competition.

\section{Duties and Authority of the Government in the Implementation of Upstream Oil and Gas Activities}

The Ministry of Energy and Mineral Resources' authorities in implementing upstream oil and gas activities is aimed at the creation of a Cooperation Contract as stated in Article 24 PP No. 35/2004 in conjunction with PP No. 34/2005, that upstream business activities are carried out by Business Entities or Permanent Establishments based on Cooperative Contract/Production Sharing Contracts (PSC) with Special Oil and Gas Work Units (SKK Oil and Gas). Although the PSC is conducted between the contractor and SKK Oil and Gas, it does not mean that the Minister does not possess authority over the activity. ${ }^{14}$ Instead, the authority of the Minister is vital in determining the primary forms and conditions of the Cooperation Contract after obtaining approval / being considered by the Head of SKK Oil and Gas. ${ }^{15}$ The minister is authorized to approve or reject requests made by oil and gas contractors regarding the extension of the period owned by PSC, as well as the transfer of part or all of the rights and obligations attached to it. ${ }^{16}$

\section{SKK Oil and Gas as A Substitute for BP Oil and Gas}

The existence of SKK Oil and Gas is a new thing in Indonesia. The legal status of SKK Oil and Gas is based on Presidential Regulation Number 95 of 2012 concerning The Transfer of the Implementation of Duties and Functions of Upstream Oil and Gas Business Activities (Perpres 95/2012), and Presidential Regulation No. 9/2013 on the Management of Upstream Oil and Gas Business Activities (Perpres NO. 9 / 2013). Is to replace the role of the Oil and Gas Implementing Agency (BP Oil and Gas) in carrying out the function of controlling and supervising upstream business activities in the oil and gas sector. ${ }^{17}$

Overall, the Constitutional Court revoked Article 1 number 23, Article 4 paragraph (3), Article 41 paragraph (2), Article 44, Article 45, Article 48 (1), Article 59 letter a, Article 61, Article 63 of the Oil and Gas Law because The Court also removed the phrase "with the Implementing Agency" in Article 11 paragraph (1); the phrase "through the Implementing Agency" in Article 20 paragraph (3); the phrase "based on

14 Redi, A., "Kontrak Karya PT Freeport Indonesia Dalam Perspektif Pancasila dan UUD NRI 1945", Jurnal Konstitusi, 13(3), 613-638, (2016), at 620.

15 Badjuri, A., "Faktor-Faktor Fundamental, Mekanisme Corporate Governance, Pengungkapan Corporate Social Responsibility (CSR) Perusahaan Manufaktur dan Sumber Daya Alam di Indonesia," Dinamika Keuangan dan Perbankan, 3(1), 38-54, (2011), at 41.

16 Disemadi, H.S., \& Roisah, K., "Kontrak Build Operate Transfer Sebagai Sarana Mewujudkan Kesejahteraan Rakyat," Jurnal Komunikasi Hukum, 5(2), 126-138, (2019) at 135.

17 Mujiburohman, D. A., "Akibat Hukum Pembubaran BP Migas," Mimbar Hukum Fakultas Hukum Universitas Gadjah Mada, 25(3), 461-475, (2013), at 470. 
consideration of the Implementing Agency and" in Article 21 paragraph (1); and "phrases Implementing Agency and" in Article 49 of the Oil and Gas Law. The entire Article was considered by the Court to conflict with Article 33 of the 1945 Constitution.

In Decision No. 36/PUU-X/2012, the Constitutional Court decided to dissolve BP Oil and Gas BP Oil and Gas only functioned to control and supervise oil and gas management and did not carry out direct management. ${ }^{18}$ As a consequence, the relationship model between BP Oil and Gas, as a state representative, with the Business Entity and Permanent Business Entities degrades the meaning/power/influence? Of state control over natural oil and gas resources and thus contradicts Article 33 of the 1945 Constitution. ${ }^{19}$ That is, through the construction of oil and gas control through BP Oil and Gas, the state lost its authority to manage and or directly appoint SOEs to manage oil and gas. Following up on the Constitutional Court's decision, Perpres 95/2012 and Perpres 9/2013 were created to fill the legal vacuum and eliminate legal uncertainties that could potentially emerge in the upstream oil and gas industry as stipulated in the PSC after the dissolution of BP Oil and Gas. It is just that the position of SKK Oil and Gas is not a state-owned legal entity (BHMN) like BP Oil and Gas but is a work unit under the minister (CQ. Minister of Energy and Mineral Resources). ${ }^{20}$

One of the statements made by the Constitutional Court decision was, "All rights and authority of BP Oil and Gas in the PSC, after this decision, are to be carried out by the Government or a State-Owned Enterprise as stipulated by the Government." One of the consequences of the decision appeared in Article l of Perpres 95/2012, which stated that the implementation the duties, functions, and management of organization of the Executive Agency for Upstream Oil and Gas Business Activities were to be transferred to the minister who carries out government affairs in the field of oil and gas, until the issuance of new regulations and Article 1 of Perpres 9/2013 that ministers who carry out government affairs in the field of energy and mineral resources, hereinafter referred to as the Minister, fostering, coordinating and overseeing the management of upstream oil and gas business activities. ${ }^{21}$ Of the two regulations, it is clear that the Government prefers the option provided by the Constitutional Court decision, which declared the dissolution of BP Oil and Gas. This decision also included a declaration to delegate the duties and authority of BP Oil and Gas to the minister who directly oversees the oil and gas sector.

Article 3 of Perpres No. 95/2012 also confirms that the entire process of managing upstream oil and gas business activities, which are being handled by the Implementing Agency for Upstream Oil and Gas Business Activities, is continued by the minister who carries out government affairs in the oil and natural gas sector by the provisions legislation. Based on the description, all rights and obligations attached to BP Oil and

18 Hukum Online, "MK: BP Migas Inskonstitusional," (2019), online: 〈https://www.hukumonline.com〉.

19 Hukum Online, "MK: BP Migas Inskonstitusional," (2019), online: 〈https://www.hukumonline.com〉.

20 Fabrikant, R., "Production Sharing Contracts in the Indonesian Petroleum Industry", Harv. Int'l. LJ, 16, 303, (1975), at 303.

21 Arizona, Y., supra note 4 at 271. 
Gas were to be moved to, and are carried out by, SKK Oil and Gases. This shift constitutes a unit under the Minister of ESDM as a substitute contract (contractual) subject in the PSC. Although BP Oil and Gas is the party that, up until this point, signed every PSC, the dissolution of BP Oil and Gas made obsolete the legal conditions of the agreement in Article 1320 BW. This article stated that if the right conditions are not fulfilled in the absence of either party, the discussed PSC does not automatically become invalid or null and void by law. Considering the sheer number of existing PSCs, the Government cannot ignore the protection of the interests of the oil and gas investors, composing trillions of invested capital. Regarding this problem in Article 2 of Perpres 95/2012, it has been confirmed that all Cooperation Contracts signed between the Implementing Agency for Upstream Oil and Gas Business Activities and Business Entities or Permanent Establishments remain in effect until their fixed period ends.

As previously explained, the PSC is a unique type of contract where both private and public law is loaded. Also contained within the government contract is the onesided will of the government. The terms of the contract were being prepared solely? By the government. The oil and gas contractor may only agree or disagree, and cannot make a counteroffer ${ }^{22} 23$ PSC Laws/language/ruling/authority is sourced from the Oil and Gas Law, which included BP Oil and Gas as a contract partner of the oil and gas contractor. By the decision of the Constitutional Court, which revoked several articles in the Oil and Gas Law concerning the existence and position of BP Oil and Gas, BP Oil and Gas was dissolved. ${ }^{24}$ With scrutiny of the logical legal flow of the formation of PSCs, it becomes clear that the institutional definition of the Government does not affect PSC operation, and does not require an agreement the oil and gas contractors relating to the Government's position besides positioning as a private entity as well as a public entity that of course there are public characteristics along with all the public jurisdiction process of change along with the legal consequences that arise attached to the position of the Government.

The PSC involving SKK Oil and Gas, the successor to BP Oil and Gas in the upstream oil and gas, does not adhere to the "B to B" (Business to Business) scheme but "B to G" (Business to Government). ${ }^{25}$ It happened because every right and obligation attached to BP Oil and Gas was transferred to SKK Oil and Gas. Thus, the legal consequences are the same, even though it is institutionally different. ${ }^{26}$ Based on the previous descriptions, it can be expressly stated that the duties and authorities of BP Oil and Gas are also the duties and authorities of SKK Oil and Gas. As a result, the authority of BP Oil and Gas is implemented by SKK Oil and Gas. In Article 12, PP No.

22 Amalia, D. S.: Tanggung Jawab Negara Dalam Pengelolaan Minyak dan Gas Bumi”, Jurnal Ilmiah FENOMENA, 12(1), 1134-1146, (2014), at 1138.

23 Pongsiri, N., "Partnerships in Oil and Gas Production-Sharing Contracts," International Journal of Public Sector Management, 17(5), 431-442, (2004), at 439.

24 Hernandoko, A., \& Imanullah, M. N., supra note 1 at 163.

25 Liu, M., Wang, Z., Zhao, L., Pan, Y., \& Xiao, F., "Production Sharing Contract: An Analysis Based on an Oil Price Stochastic Process," Petroleum Science, 9(3), 408-415, (2012), at 411.

26 Yusgiantoro, P., \& Hsiao, F. S., "Production-Sharing Contracts and Decision-Making in Oil Production: The Case of Indonesia", Energy Economics, 15(4), 245-256, (1993), at 251. 
42/2002 jo. Article 1 Perpres No. 95/2012, Article 1 and Article 2 paragraph (1) of Presidential Regulation No. 9/2013, SKK Oil and Gas has the authority to, among other things, include a)foster cooperation for the integration and synchronization of PSC contractor operational activities; b) formulate policies, budgets, and work programs for PSC contractors; c) oversee the main operational activities of PSC contractors; d) manage all PSC contractor assets that are the property of the State; e) coordinate with related parties and or agencies that are needed in the upstream oil and gas business activities. $^{27}$

If observed, one of the tasks of SKK Oil and Gas, which was previously carried out by BP Oil and Gas, is the signing of the Cooperation Contract. Perpres 95/2012 and Perpres 9/2013 essentially gave SKK Oil and Gas the authority to sign the PSC with oil and gas contractors. The dissolution of BP Oil and Gas did not cause the cancellation of the PSC because SKK Oil and Gas inherited all the functions, duties, authority, rights, and obligations arising from the PSC, which were previously within the BP Oil and Gas domain, as a result of Perpres No. 95/2012 and No. 9/2013.

\section{GOVERNMENT'S IMMUNITY RIGHTS}

The government is required to meet public service needs for the people. Primarily, the government provides those services through contractual relationships with other parties. The contract, as a legal instrument, is an essential part of legal efforts to protect state assets. The urgency of Cooperation Contracts, as a measure for the legal protection of state assets, will be discussed in the next Chapter. ${ }^{28}$ The contract provides the rules for parties in the game, which is the enactment of the contractions. Contracts involving the government, are not fully subject to private law.

One of the essential aspects of contracts which involve the government that the government has immunity in court. There exist regulations that protect the country's wealth and finances. Article 50 of Law Number 1 Concerning State Treasury states that all parties are prohibited from confiscating 1) any money or securities belonging to the state/region or an associated third party 2) money that must be deposited by a third party to the country/region; 3) movable property belonging to the state or region either within a government institution and a third party; 4) immovable property and other property rights belonging to a state or region; or 5) items belonging to third parties that are controlled by the state or region that are needed to carry out government tasks.

The urgency of issuing these rules is none other than as a legal basis for the management of state finances. The principle of prohibition of confiscation contained in Article 50 is a deviation from the principle of confiscation, as stated in Article 1131 and 1132 Civil Code. 180. One consequence of a confiscation ban on state assets, in connection with government contracts made and subject to Indonesian law, is that the government is immune from prosecution. The consequences of immunity are still

\footnotetext{
27 Pongsiri, N., supra note 23 at 439.

28 Arizona, Y., supra note 4 at 301.
} 
binding even though there is a clause stating that the release of state assets is subject to private law. ${ }^{29}$ In principle, the state will only agree to contractual relations with other parties if it is sure that it will not be harmed? / if the state wishes to engage in contractual relations with other parties, the state must not be harmed. This principle also applies universally in the interest of protecting state assets.

\section{PSC AS A MEANS FOR PROTECTING INDONESIA'S ASSETS}

As mentioned in the previous chapter, the government's contracts have different characteristics from contracts made between private law subjects because there are public elements. ${ }^{30}$ Often, when the government holds a dual role, such as that of being subject to both public law and private law, many problems are created. The contract made by the government falls under the jurisdiction of private law. The legal relationship that was born was a legal relationship in the field of civil law, public law conditions also apply. ${ }^{31}$ An important consideration for the development and fulfillment of government contracts it that the authority of officials must be received in order to sign contracts and carry out responsibilities stipulated in those contracts. ${ }^{32}$ Second, given that the legal relationship born through the contract is a civil legal relationship one, the contract is entirely subject to the principles and norms of contract law in BW. Third, given that the government acts as a contractor, in this case, the consequences of a seizure ban must be considered. . $^{33}$

\section{A. The Definition and Scope of Production Sharing Contracts}

Law No. 22/2001 concerning Oil and Gas stated that oil and gas business activities consist of upstream and downstream business activities. The scope of upstream business activities ranges from exploration and exploitation, while downstream business activities include processing, transportation, storage, and commerce. The provisions of Article 6 of the Oil and Gas Law stipulate that upstream business activities are to be carried out through Cooperation Contracts, as referred to in Article 1, number 19 of the Oil and Gas Law. The understanding of Cooperation Contracts established by Article 1 number 19 of the Oil and Gas Law is that PSCs or other forms of cooperation in exploration and exploitation activities that benefit the country and the results are used for the greatest prosperity of the people. In the Oil and Gas Law, there is no mention of PSCS, only states that the PSC is a form of a Cooperation Contract involved in upstream oil and gas business activities. However, the provisions of Article 1 number 4 Government Regulation No. 35/2004 concerning Upstream Oil and Gas Business Activities contains an explanation for PSCs. It explains that PSCs are a form of

\footnotetext{
Simamora, Y.S., supra note 3 at 103.

Amalia, D. S., supra note 22 at 1141.

Simamora, Y.S., supra note 3 at 91.

Amalia, D. S., supra note 22 at 1139.

Sondakh, J., "Bagi Hasil Investasi Sebagai Hak Masyarakat Adat Pada Wilayah Pertambangan Di Era Otonomi Daerah," Jurnal Hukum Unsrat, 23(8), 27-45, (2017) at 31.
} 
cooperation contract typically involved in upstream business activities, which are based on the principle of sharing production results. Thus, the PSC is an instrument used by the government to carry out oil and gas business activities, especially upstream. ${ }^{34}$

PSCs are regulated government contracts containing clauses. It asserts that the government is the subject of the contract. ${ }^{35}$ Regulations regarding clauses that must be in the PSC are contained in the Oil and Gas Law, Government Regulation No. 42/2002 concerning the Implementing Agency for Upstream Oil and Gas Business Activities (PP BP Oil and Gas), Perpres No. 95/2012, Perpres No. 9/2013, and Government Regulation No. 35/2004 concerning Upstream Oil and Gas Business Activities (PP Upstream Oil and Gas Business Activities) jo. Government Regulation No. 34/2005 on Amendments to Government Regulation No. 35/2004. In the PSC, the government, as the holder of mining authority, forms SKK Oil and Gas to control Upstream Business Activities in the field of oil and gas (Article 4 of Law No. 22/2001 concerning Oil and Gas). SKK Oil and Gas is a work unit under the auspices of the Minister of Energy and Mineral Resources, which replaced BP Oil and Gas in the carrying out of control, supervision, and implementation of cooperation contracts. ${ }^{36}$ Currently, SKK Oil and Gas are the primary authority responsible for signing and supervising the implementation of PSCs with Business Entities and Permanent Business Entities(PP No. 42/2002 concerning the Executive Agency for Upstream Oil and Gas Business Activities).

The Oil and Gas Law requires that every Cooperation Contract on state assets must be notified in writing to the Indonesian Republican House of Representatives (Article 11 paragraph (2) of Law No. 22/2001). This notification functions to ensure the participation of the people participating in decisions regarding the control of oil and gas exploration and exploration activities. In reality, the direct participation of the people is relatively minor because the House of Representative only can carry out oversight functions after the Cooperation Contract is signed, rather than being involved with the initial development phase before signing. ${ }^{37}$

Opponents of PSCs involving SKK Oil and Gas are called Business Entities and Permanent Business Entities. A Business Entity in Indonesia, as a legal entity, is a company that was established by applicable laws that runs a permanent type of business and was. ${ }^{38}$ Business entities, in this case, can take the form of state-owned business entities, regionally-owned business entities, cooperatives / small businesses, or private business entities. In contrast, a Permanent Business Entityis one who engages in activities within the territory of the Unitary State of Indonesia and is obliged to comply with statutory regulations in force in the country, but was established and

34 Feng, Z., Zhang, S. B., \& Gao, Y., "On Oil Investment and Production: A Comparison of Production Sharing Contracts and Buyback Contracts," Energy Economics, 42, 395-402, (2014), at 398.

35 Pongsiri, N., supra note 23 at 441.

36 Setyadi, D.S., supra note 10 at 38.

37 Qurbani, I. D., "Prinsip Hukum Perimbangan Dana Bagi Hasil Minyak dan Gas Bumi", Yuridika, 29(1), 113-123, (2014) at 119.

38 Amalia, D. S., supra note 22 at 1137. 
incorporated outside of the territory. In this PSC, each Business Entity or Permanent Business Entity is given one working area. If a Business Entity or Permanent Business Entity operates in several working areas, the Oil and Gas Law requires them to be legally separated by their respective areas. ${ }^{39}$

PSCs are active for 30 years (consisting of exploration and exploitation periods), which can be extended for no more than 20 years at a given time. The period for exploration activities is six years, which can be extended only once, for a maximum time length of 4 years, based on request from the contractor, as long as the contractor has fulfilled the minimum obligations under the Cooperation Contract the approval of SKK Oil and Gas) (Article 27 PP No. 35 of 2004).

Requests for contract extension are required to be submitted by the contractor to the Minister of Energy and Mineral Resources through SKK Oil and Gas. SKK Oil and Gas plays a role in evaluating the request for contract extensions as materials for consideration by the Minister of Energy and Mineral Resources. In this role, they may either approve or reject requests. Taken into account are considerations relating to the following: the potential of oil and gas reserves from the relevant work area, potential or certainty of the market/need for the product, and technical/economic feasibility. Requests for contract extension can be submitted no sooner than ten years, and no later than two years before the contract expires, but if the contractor has been bound by a natural gas sale and purchase agreement, the contractor can submit a contract extension sooner than the deadline.

\section{B. Rights and Obligations of Involved Parties}

As a reciprocal agreement, the PSC attaches rights and obligations to the parties. SKK Oil and Gas must fulfill the right of the contractor. The opposite is also exact: it is the obligation of the contractor to fulfill the right of SKK Oil and Gas. The Oil and Gas Law regulates the constitution of rights and obligations of the parties engaged in a Cooperation Contract, which may include some or all: ${ }^{40}$ a) State revenue; b) Working area and return; c) Fund obligation; d) Transfer of ownership of production results to; e) the period and conditions of contract extension; f) Dispute resolution; g) Obligation to supply oil and/or natural gas for domestic needs; h) Contract termination; i) Postoperative mining obligations; j) Occupational Health and Safety; k) Management of the environment; 1) Transfer of rights and obligations; m) Reporting needed; n) Field development plan; o) Prioritizing the use of domestic goods and services; p) Development of the surrounding community and guarantee of the rights of indigenous peoples, and q) Prioritizing the employment of Indonesian workers rather than those immigrating from abroad.

39 Hernandoko, A., \& Imanullah, M. N., supra note 1 at 165.

40 Breaux, T. D., \&e Antón, A. I., "Analyzing Goal Semantics for Rights, Permissions, and Obligations" In 13th IEEE International Conference on Requirements Engineering, 05, pp. 177-186, (2005) at 179-180. 
Salim H. S. presents contractor obligations according to the provisions of section $\mathrm{V}$ on PSC. ${ }^{41}$ These stipulate that contractors are obligated to: ${ }^{42}$ l) Cover all costs required to buy or rent equipment and materials; 2) Provide all technical assistance, including foreign workers; 3) providing other costs for implementing work programs including payments to third (foreign) parties who provide services to contractors; 4) Prepare and implement work programs that will be carried out quickly and by scientific methods; 5) Review environmental conditions at the beginning of the activity; 6) Take precautionary measures to protect the ecological system from threats like shipping damage, fishing, and other forms of pollution of the sea and rivers as a direct result of conducting operations; 7) Remove all equipment used from the contract area by the provisions of SKK Oil and Gas also the Government of Indonesia. The following obligations are carried out only after the contract period ends 8) Restoration of all drilling sites to standards set in Government Regulations, which aim to prevent risks to human life and property, or the environment; and 9) Annual budgeting for operational costs, estimated costs of recovery, and site acquisition for each exploration well utilized during the work program ${ }^{43}$ (all costs incurred by the contractor in the process of freeing wells and restoring the drilling location are to be covered as they fall within the category of operational costs); 10) Produce a construction plan for each commercial discovery, recovery program, and joint site acquisition, including the funding procedures for each program; 1l) Submit all copies of geological, geophysical, drilling, oil well, and production data to the Government of Indonesia through SKK Oil and Gas. The contractor can hold a copy of the original data which must be approved by the Government of Indonesia; 12) Prepare the plans for, and implement, programs for all workgroups in Indonesia to receive relevant industry training; 13) Approve the sale and shipment of oil to the Government of Indonesia as much as $25 \%$ of the total profitsharing received by the contractor, this sale is only made after commercial production; 14). Using goods and services produced in Indonesia or made by Indonesians; 15) Paying income tax to the Government of Indonesia, including the final tax on profits earned by contractors; 16)comply with all applicable regulations in Indonesia; 17) Maintain the privacy of data that is geological, geophysical, petrophysical, technical, oil wells, or otherwise protected by the contract unless the Government of Indonesia gives written permission for disclosure to a third party; and 18) Provide a minimum funding amount of USD 75,000 to SKK Oil and Gas before the annual work program starts.

The contractor's rights, as presented by Salim H. S. regarding the PSC model, are that of: ${ }^{44}$ 1) Selling, giving, or transferring all or part of their rights and authority, as stipulated in the contract, to the branch company with the condition that written permission must be received from SKK Oil and Gas; 2)Selling, giving, or transferring all or part of their rights and authority to third parties, other than branch companies, with

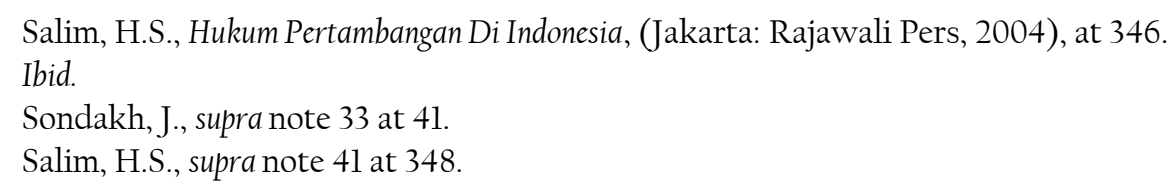


written permission from SKK Oil and Gas and the Government of Indonesia; 3) Supervising all rented equipment; 4) Entering or removing facilities from the contract area; 5) Using and accessing all data and information on geology, geophysics, drilling, oil wells and production in contract areas as collected by the Government of Indonesia; 45 6) Selling and exporting crude oil abroad; 7) Appointing representatives in Jakarta.

The obligations of SKK Oil and Gas, as stated in the provisions of Section V of the PSC model, are as follows: ${ }^{46}$ l) To take responsibility for operational management; 2) To assist and expedite the implementation of the contractor's work program by providing facilities, employees, transportation, security protection, requested entertainment, and supplies, as well as making visas, work permits ${ }^{47}$, where costs to provide the contractor as operational costs will bear this; 3) To freeing the contractor from taxes including VAT, Transfer Tax, Import Export Tax on raw materials and equipment brought to Indonesia; 4) To maintain the privacy of all original data from oil drilling operations, ${ }^{48}$ including geological, geophysical, petrophysical, and technical data as well as that relating to oil wells, unless written permission from the contractor is received; and 5) To approve the use of assets by third parties on the condition that there must be written permission from the contractor. ${ }^{49}$

The rights of SKK Oil and Gas are as follows: ${ }^{50}$ l) To receive oil and gas production results in a form pre-determined in the contract agreement between SKK Oil and Gas and the contractor, and 2) To receive income tax and year-end taxes from the contractor. In general, the payment rights received by the state (through SKK Oil and Gas) from the PSC are as follows: ${ }^{51} 1$ ) Tax payments that constitute state revenue, and 2) Non-tax payments which also compose state revenue. Tax forms of state revenue consist of: a) taxes on everyday goods and services; b) duties on imports, and other levies on imports and excise; c) local taxes and regional distribution. Non-tax state revenue is collected through the following 1) Acquisition of a part of the state, which is a part of oil and gas production that is surrendered by a business entity or permanent establishment to the state; 2) Fixed fees, such as contributions paid by business entities or permanent business entities from the work area to the state in return for opportunities to carry out exploration and exploitation activities; 3) Exploration and exploitation contributions, such as those paid by business entities to the state as compensation for taking non-renewable natural oil and gas resources; and 4). Bonuses, including signing bonuses, data compensation bonuses, production bonuses, or bonuses of any kind as obtained by SKK Oil Gas in the context of a PSC.

45 Romadhon, T. M., "Pengaturan Production Sharing Contract dalam Undang-Undang Minyak dan Gas”, Jurnal Fakultas Hukum UII, 16(1), 88-105, (2009) at 90.

46 Salim, H.S., supra note 41 at 349.

47 Qurbani, I. D., supra note 41 at 121.

48 Hernandoko, A., \& Imanullah, M. N., supra note 1 at 165.

49 Anshar, A., "Penguasaan Negara Atas Migas Sebagai Wujud Kedaulatan Atas Sumberdaya Alam Dalam Perspektif Hukum Internasional Kontemporer", Jurnal IUS Kajian Hukum dan Keadilan, $5(2), 163-176,(2017)$ at 167.

50 Salim, H.S., supra note 41 at 350.

$51 \quad$ Ibid. at 293. 


\section{Clauses Which Protect State Assets}

The clauses, being contents of the contract, are agreed upon by all involved parties. In principle, the contract clauses may be defined as either the main clause or a supporting clause. ${ }^{52}$ The main clause governs the essential elements of the contract. This main clause defines the function of the contract, also known as the contract type. Supporting clauses, commonly referred to as technical housekeeping clauses, are clauses that support or complement the main clauses. Where main clauses generally differ between contracts with different functions, supporting clauses are consistent across contract types. They usually occur within every type of contract.

The guidelines for preparation of the contract outline are as follows: ${ }^{53}$ l) A systematic, complete, and transparent methodology for production; 2) At least one clause and one concept; 3) That a title accompanies every clause (Article); 4) Clear utilization of the "3P's" Principle (Predict, Provide, and Protect); and 5). Supporting clauses occur at the end of the contract. 3P's Principle must be applied during the contract drafting process so that the risk of the dispute is minimized. This process requires the drafter to articulate and reflect on the principles, a process that may prevent future disputes. The book continually emphasizes what Scoot J. Burham calls the three P's of drafting: 1) Predict what may happen; 2) Provide for that contingency, and 3) Protect clients with a remedy. ${ }^{54}$

\section{CONCLUSION}

Legal protection for state assets related to oil and gas management include: ${ }^{55}$ a right to immunity if sued before a court of law in the event of confiscation of state assets. This protection is in place to protect the ability of the government to realize the fulfillment of public needs. The right to immunity can also be used as a bargaining chip by the state in the period before signing a PSC. Additionally, there are provisions regarding state revenue, state levies, and bonuses that are implemented in the production sharing provisions in the PSC model. Lastly, there are provisions requiring contractors to distribute a portion of the production share to meet domestic oil and gas needs. A PSC is an instrument of the Government used while entering into Oil and Gas management agreements with contractors. They are particularly relevant for contracts regarding upstream business activities. In the Oil and Gas Law, there is no mention of the PSC, which only states that the PSC is a form of a Cooperation Contract in upstream oil and gas business activities.

\footnotetext{
Romadhon, T. M., supra note 44 at 100.

Broad, R., "The Political Economy of Natural Resources: Case Studies of The Indonesian and Philippine Forest Sectors," The Journal of Developing Areas, 29(3), 317-340, (1995) at 335.

54 Burnham, S.J., Drafting Contracts Second Edition, (Virginia: Michie Company, 1993), at 2.

55 Anshar, A., supra note 48 at 170-171.
} 


\section{REFERENCES}

Adha, L. H., "Kontrak Build Operate Transfer Sebagai Perjanjian Kebijakan Pemerintah Dengan Pihak Swasta" (2011) Jurnal Dinamika Hukum, 1l(3).

Anshar, A., "Penguasaan Negara Atas Migas Sebagai Wujud Kedaulatan Atas Sumberdaya Alam Dalam Perspektif Hukum Internasional Kontemporer" (2017) Jurnal IUS Kajian Hukum dan Keadilan, 5(2).

Arizona, Y., "Perkembangan konstitusionalitas penguasaan negara atas sumber daya alam dalam putusan Mahkamah Konstitusi," (2011) Jurnal Konstitusi, 8(3).

Asikin, Z., "Perjanjian Kerjasama Antara Pemerintah dan Swasta dalam Penyediaan Infrastruktur Publik" (2013) Mimbar Hukum-Fakultas Hukum Universitas Gadjah Mada, 25(1).

Amalia, D. S. "Tanggung Jawab Negara Dalam Pengelolaan Minyak Dan Gas Bumi" (2014) Jurnal Ilmiah FENOMENA, 12(1).

Badjuri, A., "Faktor-Faktor Fundamental, Mekanisme Coorporate Governance, Pengungkapan Coorporate Social Responsibility (CSR) Perusahaan Manufaktur dan Sumber Daya Alam di Indonesia" (2011) Dinamika Keuangan dan Perbankan, 3(1), 38-54.

Breaux, T. D., \&e Antón, A. I., "Analyzing goal semantics for rights, permissions, and obligations" (2005) In the 13th IEEE International Conference on Requirements Engineering, 05.

Broad, R., "The political economy of natural resources: Case studies of the Indonesian and Philippine forest sectors" (1995) The Journal of Developing Areas, 29(3).

Burnham, S.J., Drafting Contracts second edition, (Virginia: Michie Company, 1993).

Disemadi, H., \& Roisah, K., "The Enforcement of Business Competition Law by the Police: An Indonesian Experience” (2019) Lentera Hukum, 6(2).

Disemadi, H. S., \& Roisah, K., "Kontrak Build Operate Transfer Sebagai Sarana Mewujudkan Kesejahteraan Rakyat" (2019) Jurnal Komunikasi Hukum, 5(2).

Fabrikant, R., "Production sharing contracts in the Indonesian petroleum Industry" (1975) Harv. Int'l. LJ, 16, 303.

Feng, Z., Zhang, S. B., \& Gao, Y., "On oil investment and production: A comparison of production sharing contracts and buyback contracts" (2014) Energy Economics, 42.

Hernandoko, A., \& Imanullah, M. N., "Implikasi Berubahnya Kontrak Bagi Hasil (Product Sharing Contract) Ke Kontrak Bagi Hasil Gross Split Terhadap Investasi Minyak dan Gas Bumi Di Indonesia" (2018) Privat Law, 6(2).

Hukum Online, "MK: BP Migas Inskonstitusional”, 3 August 2019 https://www.hukumonline.com.

Liu, M., Wang, Z., Zhao, L., Pan, Y., \& Xiao, F., "Production sharing contract: An analysis based on an oil price stochastic process" (2012) Petroleum Science, 9(3).

Mujiburohman, D. A., "Akibat Hukum Pembubaran BP Migas" (2013) Mimbar HukumFakultas Hukum Universitas Gadjah Mada, 25(3). 
Pongsiri, N., "Partnerships in oil and gas production-sharing contracts" (2004) International Journal of Public Sector Management, 17(5).

Redi, A., "Kontrak Karya PT Freeport Indonesia dalam Perspektif Pancasila dan UUD NRI 1945" (2016) Jurnal Konstitusi, 13(3).

Romadhon, T. M., "Pengaturan Production Sharing Contract dalam undang-Undang Minyak dan Gas" (2009) Jurnal Fakultas Hukum UII, 16(1).

Salim, H.S., Hukum Pertambangan Di Indonesia, (Jakarta: Rajawali Pers, 2004).

Sondakh, J., "Bagi Hasil Investasi Sebagai Hak Masyarakat Adat Pada Wilayah Pertambangan Di Era Otonomi Daerah" (2017) Jurnal Hukum Unsrat, 23(8).

Setyadi, D.S., Aspek Hukum Administrasi Eksplorasi dan Eksploitasi Minyak dan Gas Bumi di Indonesia, (Surabaya: Nusantara Makmur, 2007).

Simamora, Y.S., Prinsip Hukum Kontrak Dalam Pengadaan Barang dan Jasa Oleh Pemerintah, (Yogyakarta: Laksbang PRESSindo, 2009).

Yusgiantoro, P., \& Hsiao, F. S., "Production-sharing contracts and decision-making in oil production: The case of Indonesia" (1993) Energy Economics, 15(4).

Qurbani, I. D., "Prinsip Hukum Perimbangan Dana Bagi Hasil Minyak dan Gas Bumi” (2014) Yuridika, 29(1). 